\title{
Pollen types collected by Tetragonisca angustula (Hymenoptera: Apidae) in dry vegetation in Northeastern Brazil
}

\author{
Jaílson Santos de NOVAIS ${ }^{1,2}$, Maria LÚcia ABSY² and Francisco de Assis Ribeiro dos SANTOS 3 \\ ${ }^{1}$ Centro de Formação Interdisciplinar and Laboratório de Botânica Taxonômica, Universidade Federal do Oeste do Pará (UFOPA), \\ Rua Vera Paz, s/n, Salé, 68035-110 Santarém, PA, Brazil; e-mail: jailson.novais@ufopa.edu.br \\ ${ }^{2}$ Laboratório de Palinologia, Coordenação de Biodiversidade, Instituto Nacional de Pesquisas da Amazônia (INPA), Av. André \\ Araújo, 2.936, Petrópolis, 69067-375 Manaus, AM, Brazil; e-mail: lucia.absy@gmail.com \\ ${ }^{3}$ Laboratório de Micromorfologia Vegetal, Departamento de Ciências Biológicas, Universidade Estadual de Feira de Santana \\ (UEFS), Av. Transnordestina, s/n, 44036-900 Feira de Santana, BA, Brazil; e-mail: fasantos@uefs.br
}

Key words. Hymenoptera, Apidae, Tetragonisca angustula, stingless bee foraging, caatinga dry vegetation, entomopalynology, melissopalynology, pot-pollen

\begin{abstract}
Knowing the floral origin of the pollen collected by native bees in Neotropical ecosystems enables us to understand the dynamics of the interdependent relationships between the insects and the native flora. The objectives of this study were to: (i) investigate the spectrum of plant species from which pollen is collected by Tetragonisca angustula in caatinga (dry vegetation) areas in the semiarid region of Northeastern Brazil; (ii) identify pollen types that could be used as regional geographical markers and (iii) determine the pollen niche breadth and the pattern of use of floral resources by this stingless bee. In total, 23 samples of the pollen stored by T. angustula were collected monthly and subjected to acetolysis. Of the 45 pollen types identified that of Prosopis juliflora (Fabaceae) and Solanum (Solanaceae) were the most frequently represented in the samples and 19 were collected by the bees at both study sites. Species characteristic of caatinga, such as Poincianella pyramidalis (Tulasne) L.P. Queiroz and Senna macranthera (de Candolle ex Colladon) H.S. Irwin \& Barneby, were among the pollen identified and they were used as indicators of the geographical origin of the samples. The average values of the pollen niche breadth ( $\left.\mathrm{H}^{\prime}\right)$ and equitability $\left(\mathrm{J}^{\prime}\right)$ indicate that $T$. angustula is a generalist and homogeneous forager of the floral resources in caatinga.
\end{abstract}

\section{INTRODUCTION}

Over the past several decades, deforestation, habitat loss and the introduction of exotic species have resulted in a decline in populations of native pollinators. This phenomenon has led the international scientific community to attempt to understand the implications of this decline for global ecosystems and propose mechanisms for reducing this decline (Allen-Wardell et al., 1998; International Pollinators Initiative, 1999; Biesmeijer et al., 2006; Freitas et al., 2009; Burkle \& Alarcón, 2011; Giannini et al., 2012). As the environmental services provided by native bees in particular are important it is essential to understand those aspects of their biology, behaviour and ecology that can be used to develop conservation initiatives designed to maintain pollination (Allen-Wardell et al., 1998).

The pollinators are primarily female bees that collect pollen as the main protein source for themselves and their larvae (Michener, 2007). In the Neotropical region, however, it is difficult to carry out continuous and systematic studies of the flora that provide this protein diet for native bees. In Brazil, such studies have been ongoing for decades; however, they have not been done in all the biomes in Brazil (Barth, 2004; Borges et al., 2006).

Among the Brazilian biomes, the phytogeographic domain of caatinga is the largest gap in our botanical knowledge, largely because of the erroneous belief that this type of vegetation originated from the modification of another plant formation (Giulietti et al., 2004). According to Queiroz (2006), historically, the species diversity of the flora of the caatinga is considered to be low and include few endemics. It is suggested that the caatinga does not have an autochthonous flora and that most of its elements are derived from chaco and Atlantic rain forest (Rizzini, 1963; Andrade-Lima, 1981). These hypotheses were subsequently rejected (Prado \& Gibbs, 1993). Recent studies indicate that the flora of the caatinga is surprisingly diverse (Giulietti et al., 2002, 2004, 2009; Albuquerque et al., 2012) and includes 4,320 species of angiosperms (Forzza et al., 2010), which have relationships with a range of pollinators including 187 species of native bees (Zanella \& Martins, 2003). There is a mosaic of different ecosystems in the dry vegetation in the caatinga, which covers an area of approximately $800,000 \mathrm{~km}^{2}$ and practically the entire semiarid climate region in Brazil, from the northeast through a region north of the State of Minas Gerais (Prado, 2003; Giulietti et al., 2004).

Among the Meliponini reported in the Brazilian caatinga, Tetragonisca sp. group angustula (Latreille, 1811 ) is one of the most well-known and studied groups. The geographical distribution of this group of stingless bees goes beyond the Brazilian territory, extending from Mexico to Argentina (Camargo \& Pedro, 2012). Although the pollen collected by $T$. angustula has been studied in many different types of Brazilian vegetation 


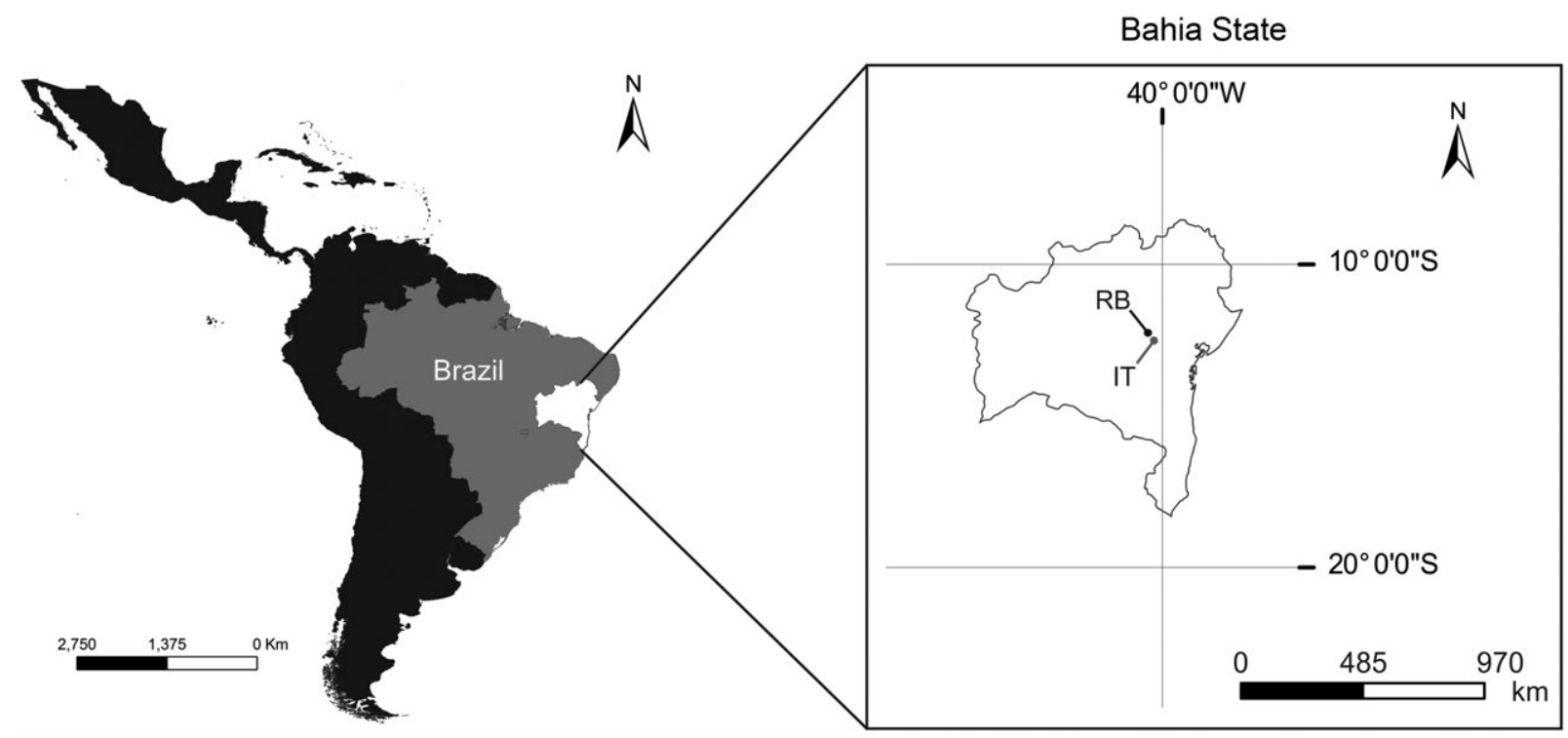

Fig. 1. The map on the left indicates the location of Brazil (light grey) in South America (black). The map on the right shows the state of Bahia, indicating the study areas at Itaberaba (IT) and Ruy Barbosa (RB).

(Iwama \& Melhem, 1979; Imperatriz-Fonseca et al., 1984; Carvalho et al., 1999; Morgado et al., 2011; Novais \& Absy, 2013), few studies have been done in caatinga. Novais et al. (2006) performed a palynological study of the honey of this species collected in a hyperxerophytic caatinga region at the Canudos Biological Station in the northeastern micro-region of Bahia State. Recently, the pollen contents of honey from $T$. angustula colonies at Itaberaba and Ruy Barbosa in Bahia State were investigated (Novais et al., in press). However, there are no reports of palynological studies of the pollen stored by $T$. angustula foraging in caatinga vegetation.

Because there is no information on the floral spectrum foraged by $T$. angustula for collecting pollen in dry vegetation in the caatinga region of the Brazilian semiarid region we asked the following questions: (i) what pollen types reflect the flora visited by $T$. angustula in the caatinga of Bahia?; (ii) which of the various pollen types collected by this species can be used as regional geographical markers?, and (iii) does the pattern of use of pollen resources in the areas of caatinga investigated indicate a homogeneous or heterogeneous use of the local flora?

\section{MATERIAL AND METHODS}

\section{Study areas}

This study was carried out in the municipalities of Itaberaba $\left(12^{\circ} 26^{\prime} 18.8^{\prime \prime} \mathrm{S}, 40^{\circ} 13^{\prime} 12.7^{\prime \prime} \mathrm{W}\right)$ and Ruy Barbosa $\left(12^{\circ} 17^{\prime} 27.6^{\prime \prime} \mathrm{S}\right.$, $\left.40^{\circ} 30^{\prime} 03.0^{\prime \prime} \mathrm{W}\right)$, which are located in the semiarid climate zone in the state of Bahia, Northeastern Brazil (Fig. 1). The annual precipitation in this area does not exceed $800 \mathrm{~mm}$ and the average temperature is approximately $25^{\circ} \mathrm{C}$ (EMBRAPA, 2013).

The most diverse plant families in the region include Fabaceae, Euphorbiaceae, Apocynaceae, Orchidaceae, Rubiaceae and Asteraceae, of which there are more than 120 recognized species (Cardoso \& Queiroz, 2008). Depending on altitude, various plant formations can be distinguished locally, from caatinga with palm trees at lower altitudes (up to $450 \mathrm{~m}$ ), to vegetation similar to savanna and areas of rupestrian fields (at approximately $900 \mathrm{~m}$ ) (Cardoso \& Queiroz, 2008).

\section{Sampling and laboratory processing}

Samples of pollen (23 in total) collected from stores in $T$. angustula colonies in the study areas were examined. At Itaberaba, samples were collected $(n=10)$ monthly during 2011, with the exception of July and November when there was a scarcity of pollen in the colonies. At Ruy Barbosa, the samples were collected monthly $(n=13)$ between October 2010 and December 2011, with the exception of June and November. Each month, the samples were collected from the same colony, mainly from the five pollen pots that had been sealed most recently by the bees, which were usually of a lighter colour than older pots. The material was collected from the food pots using pieces of disposable plastic straws (approximately $3 \mathrm{~cm}$ ), which were packed in lidded pots, labelled and kept in a refrigerator until used in the laboratory procedures.

The protocol adopted was that of Novais \& Absy (2013), which included drying the material in an oven at $40^{\circ} \mathrm{C}$ to stabilize the weight, dissolving in warm water and $95 \%$ ethanol, dehydrating in glacial acetic acid and acetolysis (Erdtman, 1960).

For each sample, three slides were prepared using glycerin gelatin and at least 500 pollen grains were quantified and identified using optical microscopy. The botanical identification of the pollen types was determined using catalogues (Roubik \& Moreno, 1991; Silva, 2007) and the pollen library at the Laboratory of Plant Micromorphology of Bahia State University at Feira de Santana. Because each pollen type represents a morphological entity that potentially includes various species or genera (Joosten \& de Klerk, 2002), the author was cited for each species when, for the first time, the taxonomic entities are referred to in the text.

After the microscopic analysis, the classes of occurrence (C.O.) were established based on the presence or absence of each pollen type in the samples as follows: $r$ - rare (present in $<10 \%$ of samples); i - infrequent (10-20\%); f - frequent $(21-50 \%)$; and vf - very frequent $(>50 \%)$ (Jones \& Bryant, 1996). These classes do not consider the number of pollen grains in each sample. 
TABLE 1. Pollen spectrum showing monthly frequency (\%), classes of occurrence (C.O.) and total number of pollen types in samples of pollen stored by Tetragonisca angustula in 2011 at Itaberaba, located in the semiarid region of Bahia in Northeastern Brazil. Values from Shannon-Weaver's diversity Index (H') and Pielou's equitability index (J') are shown. C.O.: R - rare; I - infrequent; F - frequent; VF - very frequent.

\begin{tabular}{|c|c|c|c|c|c|c|c|c|c|c|c|c|}
\hline Plant family & Pollen type & Jan & Feb & Mar & Apr & May & Jun & Aug & Sep & Oct & Dec & C.O. \\
\hline \multirow[t]{2}{*}{ Amaranthaceae } & Alternanthera brasiliana & - & - & - & - & - & - & 0.19 & - & - & - & $\mathrm{I}$ \\
\hline & Gomphrena demissa & - & - & - & 0.78 & - & - & - & - & 0.17 & - & I \\
\hline Anacardiaceae & Schinus & - & - & - & - & - & - & - & 0.74 & - & 0.71 & I \\
\hline Arecaceae & Geonoma & - & - & - & - & - & - & - & - & - & 3.91 & I \\
\hline \multirow[t]{2}{*}{ Asteraceae } & Asteraceae type & - & - & - & 0.58 & - & - & - & - & - & - & $\mathrm{I}$ \\
\hline & Mikania & 0.18 & - & 0.37 & - & 0.57 & - & - & 0.18 & 0.17 & 0.53 & VF \\
\hline Cactaceae & Cereus & - & - & - & - & - & - & - & - & - & 0.36 & I \\
\hline Capparaceae & Capparis & - & - & - & - & - & - & - & - & - & 1.60 & I \\
\hline Cucurbitaceae & Cayaponya & - & - & - & - & - & - & - & - & - & 0.18 & I \\
\hline Euphorbiaceae & Alchornea & - & 3.86 & 2.38 & - & - & - & 0.38 & - & - & - & $\mathrm{F}$ \\
\hline \multirow[t]{8}{*}{ Fabaceae } & Caesalpinioideae 1 & 90.57 & - & - & - & - & - & - & - & - & - & I \\
\hline & Caesalpinioideae 2 & - & 5.33 & - & - & - & 7.90 & - & - & - & - & I \\
\hline & Copaifera langsdorfii & - & - & - & 0.19 & - & - & - & - & - & - & I \\
\hline & Poincianella pyramidalis & 0.18 & 0.18 & 1.47 & 0.78 & 1.13 & - & - & - & 2.43 & 1.78 & VF \\
\hline & Prosopis juliflora & 4.62 & 1.29 & 12.82 & 15.92 & 2.27 & 43.75 & 14.34 & 24.58 & 21.66 & 46.98 & VF \\
\hline & Senna macranthera & - & 84.56 & 1.47 & 0.97 & 0.38 & 7.54 & 2.45 & - & 1.21 & 4.80 & VF \\
\hline & Senna rizzinni & - & - & - & - & - & - & - & - & - & 1.07 & $\mathrm{I}$ \\
\hline & Zornia echinocarpa & - & - & - & 0.97 & 0.57 & 0.92 & - & - & - & 0.18 & $\mathrm{~F}$ \\
\hline \multirow[t]{2}{*}{ Malpighiaceae } & Byrsonima & - & - & - & - & - & 0.37 & - & - & - & - & I \\
\hline & Heteropterys & - & 3.68 & - & 2.91 & - & - & 4.15 & - & 18.37 & 2.31 & $\mathrm{~F}$ \\
\hline \multirow[t]{2}{*}{ Malvaceae } & Quararibea & 2.59 & - & - & - & - & - & - & - & - & 11.74 & I \\
\hline & Waltheria & - & - & 60.62 & 16.50 & - & - & - & - & 3.47 & - & $\mathrm{F}$ \\
\hline Melastomataceae & Clidemia hirta & - & - & - & - & - & - & - & - & - & 0.71 & $\mathrm{I}$ \\
\hline Moraceae & Brosimum & 1.85 & - & - & - & - & 19.49 & 50.00 & 73.01 & 50.95 & 4.27 & VF \\
\hline Myristicaceae & Virola & - & - & - & - & - & 1.29 & 20.00 & - & - & - & $\mathrm{I}$ \\
\hline Myrtaceae & Myrcia & - & - & 0.18 & - & 5.10 & 2.02 & 0.19 & - & - & 1.25 & $\mathrm{~F}$ \\
\hline Phytolaccaceae & Microtea & - & - & 1.28 & - & - & - & - & - & - & - & $\mathrm{I}$ \\
\hline Solanaceae & Solanum & - & 1.10 & 19.05 & 60.39 & 83.55 & 16.54 & 8.30 & 1.48 & 1.56 & 16.90 & VF \\
\hline Urticaceae & Cecropia & - & - & 0.37 & - & 6.43 & 0.18 & - & - & - & - & $\mathrm{F}$ \\
\hline \multirow[t]{5}{*}{ Undetermined } & - & - & - & - & - & - & - & - & - & - & 0.71 & $\mathrm{I}$ \\
\hline & TOTAL & 100.00 & 100.00 & 100.00 & 100.00 & 100.00 & 100.00 & 100.00 & 100.00 & 100.00 & 100.00 & - \\
\hline & Number of pollen types & 6 & 7 & 10 & 10 & 8 & 10 & 9 & 5 & 9 & 17 & - \\
\hline & H'Index & 0.42 & 0.66 & 1.20 & 1.21 & 0.70 & 1.58 & 1.42 & 0.68 & 1.33 & 1.79 & - \\
\hline & J' Index & 0.24 & 0.34 & 0.52 & 0.52 & 0.33 & 0.69 & 0.65 & 0.43 & 0.61 & 0.63 & - \\
\hline
\end{tabular}

\section{Ecological analysis}

The pollen niche breadth of $T$. angustula indicated by each sample was estimated using Shannon-Weaver's diversity index (H') (Shannon \& Weaver, 1949), which was calculated using the following formula:

$$
H^{\prime}=-\sum_{i}^{n} p_{i} \cdot \ln p_{i}
$$

In the above equation, $p_{i}$ is the proportion of each pollen type $i$ in the sample. This proportion is given by $\frac{n_{i}}{N}$, where $n_{i}$ is the number of grains of each pollen type $i$ and $N$ the total number of pollen grains in the sample.

Pielou's equitability index (J') (Pielou, 1977) was used to indicate the dynamics of the use of pollen resources by the bees. This was calculated using the following equation:

$$
J^{\prime}=\frac{H^{\prime}}{H^{\prime} \max }
$$

In this equation, $H^{\prime}$ max is the natural logarithm of the total number of different pollen types $\left(S_{e}\right)$ in the sample; $H^{\prime} \max =$ $\ln S_{e}$. The J' index varies from 0 to 1 . Values between 0 and 0.5 indicate a heterogeneous use of the local flora and those between 0.5 and 1 indicate a homogeneous use.

All analyses were performed using PAST (Palaeontological Statistics) software version 2.16 (Hammer et al., 2001).

\section{RESULTS}

Our data indicate that $T$. angustula used a large number of plant species as 45 pollen types are listed in the spectra (Tables 1 and 2). Of these 19 were common to both study areas, 10 were recorded only in the samples from Itaberaba and 16 only in the samples from Ruy Barbosa. In total, 29 pollen types belonging to 18 plant families were recorded in the samples from Itaberaba (Table 1) and 35 from 25 families in the samples from Ruy Barbosa (Table 2). Of the plant families the Fabaceae was the most frequently represented family, with eight morphologically different pollen types (Tables 1 and 2). 
TABLE 2. Pollen spectrum showing monthly frequency (\%), classes of occurrence (C.O.), and total number of pollen types recorded in the samples of the pollen stored by Tetragonisca angustula from October 2010 to December 2011 at Ruy Barbosa, located in the semiarid region of Bahia in Northeastern Brazil. Values from Shannon-Weaver's diversity index (H') and Pielou's equitability index (J') are shown. C.O.: R - rare; I - infrequent; F - frequent; VF - very frequent.

\begin{tabular}{|c|c|c|c|c|c|c|c|c|c|c|c|c|c|c|c|}
\hline \multirow{2}{*}{ Plant family } & \multirow{2}{*}{ Pollen type } & \multicolumn{3}{|c|}{2010} & \multicolumn{10}{|c|}{2011} & \multirow{2}{*}{ O. } \\
\hline & & Oct & Nov & Dec & Jan & Feb & Mar & Apr & May & Jul & Aug & Sep & Oct & Dec & \\
\hline \multirow[t]{2}{*}{ Amaranthaceae } & Amaranthaceae type & - & - & - & - & 1.57 & - & - & - & - & - & - & - & - & $\mathrm{R}$ \\
\hline & Gomphres & - & - & 1.25 & - & - & - & - & - & - & - & - & - & - & $\mathrm{R}$ \\
\hline Anacardiaceae & Schinus & 2.98 & 6.35 & - & 2.48 & 0.52 & 2.12 & - & 2.96 & 47.96 & 17.03 & 4.03 & 8.23 & 29.06 & VF \\
\hline Annonaceae & Annona & - & - & - & - & - & - & - & 0.17 & - & - & - & - & - & $\mathrm{R}$ \\
\hline Apiaceae & Apiaceae ty & 0.35 & 0.69 & - & - & - & - & - & - & 0.53 & 1.79 & - & 0.16 & 0.75 & $\mathrm{~F}$ \\
\hline Arecaceae & Geonoma & - & 0.34 & - & 0.18 & 0.17 & 0.39 & - & - & - & 0.54 & - & - & 1.32 & $\mathrm{~F}$ \\
\hline \multirow[t]{2}{*}{ Asteraceae } & Asteraceae & - & - & 0.71 & - & - & - & - & - & - & - & - & - & - & $\mathrm{R}$ \\
\hline & Mikania & - & - & - & - & 0.52 & 0.19 & - & 0.17 & - & - & - & - & - & $\mathrm{F}$ \\
\hline Burseraceae & Protium & - & - & 0.18 & - & - & - & - & - & - & - & - & - & - & $\mathrm{R}$ \\
\hline Capparaceae & Capparis & - & - & 0.18 & - & - & - & - & - & - & - & - & - & - & $\mathrm{R}$ \\
\hline Convolvulaceae & Evolvulus & - & - & - & - & - & - & - & - & - & - & 0.18 & - & - & $\mathrm{R}$ \\
\hline \multirow[t]{2}{*}{ Euphorbiaceae } & Croton & - & - & - & - & - & - & - & - & - & - & - & 0.47 & - & $\mathrm{R}$ \\
\hline & Euphorbia & - & 0.17 & - & - & - & - & - & - & - & - & - & - & - & $\mathrm{R}$ \\
\hline \multirow[t]{5}{*}{ Fabaceae } & Caesalpinioide & - & 0.34 & - & 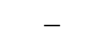 & - & - & - & 0.52 & - & - & - & - & - & $\mathrm{I}$ \\
\hline & $\begin{array}{l}\text { Poincianella } \\
\text { pyramidalis }\end{array}$ & 0.18 & - & 0.71 & 0.35 & 0.17 & - & - & - & - & - & - & - & 6.60 & $\mathrm{~F}$ \\
\hline & Prosopis juliflora & 80.74 & 71.01 & 17.97 & 80.53 & 76.66 & 49.33 & 54.91 & 12.37 & 28.77 & 53.41 & 85.11 & 81.06 & 11.51 & VF \\
\hline & Senna macranthera & 2.28 & 1.20 & - & 3.19 & - & - & 14.15 & 5.05 & 1.95 & 5.38 & 5.78 & 4.50 & 0.75 & VF \\
\hline & Zornia echinocarpa & - & - & - & - & 13.94 & 0.77 & - & - & - & - & - & - & - & I \\
\hline Lamiaceae & Hyptis & - & - & - & - & - & - & - & - & - & - & 0.18 & - & - & $\mathrm{R}$ \\
\hline Lythraceae & Lythrac & - & - & - & - & - & - & - & 6.97 & - & - & - & - & - & $\mathrm{R}$ \\
\hline Malpighiaceae & Heter & - & 3.95 & 19.57 & - & 2.61 & 36.61 & - & 11.67 & - & - & 0.70 & 0.47 & 35.47 & VF \\
\hline \multirow[t]{3}{*}{ Malvaceae } & Pseudobombax & - & - & - & - & - & - & - & - & - & - & - & - & 1.13 & $\mathrm{R}$ \\
\hline & Quararibea & - & 0.17 & - & - & - & - & - & 0.52 & - & - & - & - & - & I \\
\hline & Waltheria & - & 0.86 & - & - & 1.92 & 0.19 & - & - & - & - & - & - & - & $\mathrm{F}$ \\
\hline Melastom & Clidemia hirta & - & - & - & - & - & - & - & 0.87 & - & - & - & - & - & $\mathrm{R}$ \\
\hline Meliaceae & Trichilia hirta & - & - & - & - & - & - & - & - & - & - & - & 1.09 & - & $\mathrm{R}$ \\
\hline Moraceae & Brosimum & 11.56 & 6.35 & - & 13.27 & 0.35 & 6.55 & 6.04 & 2.44 & 10.66 & 16.67 & 1.93 & 1.24 & - & VF \\
\hline \multirow[t]{2}{*}{ Myrtaceae } & Myrcia 1 & - & - & - & - & - & - & - & - & - & - & - & - & 2.26 & $\mathrm{R}$ \\
\hline & Myrcia 2 & - & - & - & - & - & - & - & - & 1.95 & 0.72 & - & - & - & I \\
\hline Phyllanthaceae & Phyllanthus & - & - & - & - & 0.52 & - & - & 1.39 & - & - & - & - & - & I \\
\hline Plantaginaceae & Scoparia dulcis & - & - & - & - & - & - & - & - & - & - & - & 1.09 & - & $\mathrm{R}$ \\
\hline Rubiaceae & Borreria verticillata & - & - & - & - & - & - & - & - & - & 0.18 & - & - & 0.57 & I \\
\hline Rutaceae & Citrus & - & 5.49 & - & - & - & - & - & - & - & - & - & - & 6.04 & I \\
\hline Solanaceae & Solanum & 1.93 & 3.09 & 57.12 & - & 1.05 & 3.85 & 24.91 & 54.88 & 8.17 & 4.30 & 2.10 & 1.71 & 4.53 & $\mathrm{VF}$ \\
\hline \multirow[t]{5}{*}{ Urticaceae } & Cecropia & - & - & 2.31 & - & - & - & - & - & - & - & - & - & - & $\mathrm{R}$ \\
\hline & TOTAL & 100.00 & 100.00 & 100.00 & 100.00 & 100.00 & 100.00 & 100.00 & 100.00 & 100.00 & 100.00 & 100.00 & 100.001 & 100.00 & - \\
\hline & No. of pollen types & 7 & 13 & 9 & 6 & 12 & 9 & 4 & 13 & 7 & 9 & 8 & 10 & 12 & - \\
\hline & H' Index & 0.72 & 1.18 & 1.18 & 0.68 & 0.89 & 1.19 & 1.12 & 1.55 & 1.34 & 1.38 & 0.65 & 0.80 & 1.76 & - \\
\hline & J' Index & 0.37 & 0.46 & 0.54 & 0.38 & 0.36 & 0.54 & 0.81 & 0.60 & 0.69 & 0.63 & 0.31 & 0.35 & 0.71 & - \\
\hline
\end{tabular}

The main pollen types present in the samples collected at Itaberaba include the following: Brosimum, Prosopis juliflora, Senna macranthera and Solanum (Table 1). At Ruy Barbosa, the main types were Brosimum, Heteropterys, Prosopis juliflora, Schinus, Senna macranthera and Solanum (Table 2). These pollen types were present in more than $50 \%$ of the samples analyzed ("very frequent" class of occurrence) and greater than $10 \%$ in at least one of the samples.
T. angustula very frequently collected pollen from Prosopis juliflora (Swartz) de Candolle. In addition to being present in all of the pollen samples analyzed from both study areas $(n=23)$, $P$. juliflora occurred with a frequency of greater than $10 \%$ in 20 of the samples (86.96\%) (Tables 1 and 2). The second most represented pollen type was Solanum, which occurred in $90 \%$ of the samples from Itaberaba and $92.31 \%$ of those from Ruy Barbosa. The third most used pollen type at Itaberaba was Senna macranthera, which occurred in $80 \%$ of the sam- 


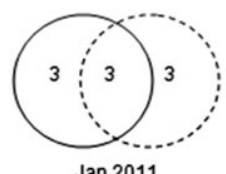

Jan 2011

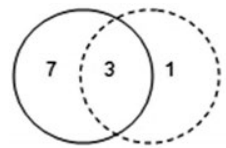

Apr 2011

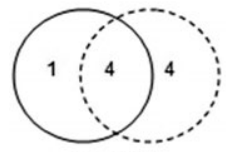

Sep 2011

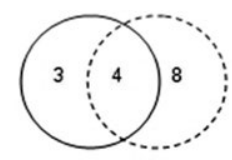

Feb 2011

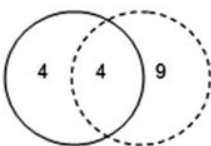

May 2011

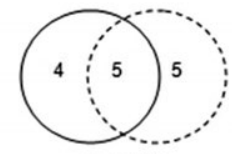

Oct 2011

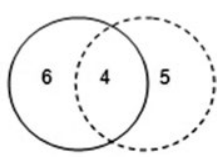

Mar 2011

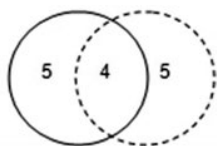

Aug 2011

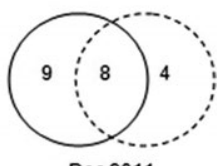

Dec 2011
Fig. 2. Diagrams comparing the number of exclusive and shared pollen types stored each month by Tetragonisca angustula foraging in caatinga vegetation in Northeastern Brazil in the municipalities of Itaberaba (solid circles) and Ruy Barbosa (dashed circles). Only months in which material was collected at both locations were included in this analysis.

ples from this municipality, followed by Poincianella pyramidalis (70\%), Mikania (60\%), Brosimum (60\%), Myrcia (50\%) and Heteropterys (50\%). At Ruy Barbosa, Brosimum and Schinus each occurred in $84.62 \%$ of the samples, followed by Senna $(76.92 \%)$ and Heteropterys $(61.54 \%)$.

At Itaberaba, only the Mikania and Poincianella pyramidalis pollen types occurred at a frequency lower than $10 \%$ in more than $50 \%$ of the samples (Table 1). At Ruy Barbosa, the pollen types included in the "very frequent" class of occurrence demonstrated a greater than $10 \%$ frequency in at least one sample (Table 2). Although a large number of pollen types were recorded, less than $25 \%$ of these were found consistently at a high percentage (>10\%) (Ramalho et al., 1985) in the T. angustula collections (Tables 1 and 2).

In 2011, eight pollen types were found in at least three consecutive months at Itaberaba, Poincianella pyramidalis (Jan-May), Prosopis juliflora (Jan-Dec), Solanum (Feb-Dec), Senna macranthera (Feb-Aug), Zornia echinocarpa (Apr-May), Myrcia (May-Aug), Brosimum (Jun-Dec) and Mikania (Sep-Dec). The occurrence of these pollen types in consecutive months was more evident in the second half of 2011 (Table 1).

At Ruy Barbosa, eight pollen types were also found in at least three consecutive months between Oct 2010 and Dec 2011: Prosopis juliflora (Oct 2010-Dec 2011), Solanum (Oct-Dec 2010 and Feb-Dec 2011), Poincianella pyramidalis (Dec 2010-Feb 2011), Brosimum (Jan-Oct 2011), Geonoma (Jan-Mar 2011), Schinus

TABLE 3. Botanical discrimination and total monthly number (2011) of pollen types that were recorded simultaneously in the pollen spectra obtained for 2 semiarid regions in Bahia in Northeastern Brazil. The data are derived from the palynological analysis of the pollen stored by Tetragonisca angustula.

\begin{tabular}{|c|c|c|c|c|c|c|c|c|c|c|c|}
\hline Plant family & Pollen type & Jan & Feb & Mar & Apr & May & Aug & Sep & Oct & Dec & Local plant species related to pollen types \\
\hline Anacardiaceae & Schinus & & & & & & & o & & o & Anacardium occidentale Linnaeus \\
\hline Arecaceae & Geonoma & & & & & & & & & o & $\begin{array}{l}\text { Geonoma pauciflora Martius } \\
\text { G. pohliana Martius }\end{array}$ \\
\hline Asteraceae & Mikania & & & o & & o & & & & & $\begin{array}{l}\text { Mikania cordifolia (Linnaeus f.) Willdenow } \\
\text { M. elliptica de Candolle } \\
\text { M. obovata de Candolle }\end{array}$ \\
\hline Fabaceae & Poincianella pyramidalis & o & o & & & & & & & o & $\begin{array}{l}\text { Poincianella pluviosa (de Candolle) } \\
\text { L.P. Queiroz }\end{array}$ \\
\hline Fabaceae & Prosopis juliflora & o & o & o & o & o & o & o & o & o & Prosopis juliflora (Swartz) de Candolle \\
\hline Fabaceae & Senna macranthera & & & & o & o & o & & o & o & $\begin{array}{l}\text { Senna macranthera var. micans (Nees) } \\
\text { H.S. Irwin }\end{array}$ \\
\hline Malpighiaceae & Heteropterys & & o & & & & & & o & o & $\begin{array}{l}\text { Heteropterys aff. fluminensis (Griseb.) } \\
\text { W.R. Anderson } \\
\text { H. macrostachya A. Jussieu } \\
\text { H. perplexa W.R. Anderson }\end{array}$ \\
\hline Malvaceae & Waltheria & & & o & & & & & & & Waltheria indica Linnaeus \\
\hline Moraceae & Brosimum & o & & & & & o & o & o & & $\begin{array}{l}\text { Brosimum gaudichaudii Trécul } \\
\text { B. guianense (Aublet) Huber }\end{array}$ \\
\hline Myrtaceae & Myrcia 1 & & & & & & & & & o & $\begin{array}{l}\text { Myrcia blanchetiana (O. Berg) Mattos } \\
\text { M. guianensis (Aublet) de Candolle } \\
\text { M. rostrata de Candolle } \\
\text { M. splendens (Swartz) de Candolle }\end{array}$ \\
\hline Solanaceae & Solanum & & o & o & o & o & o & o & o & o & $\begin{array}{l}\text { Solanum caavurana Vellozo } \\
\text { S. crinitum Lamarck } \\
\text { S. depauperatum Dunal } \\
\text { S. jabrense Agra \& M. Nee } \\
\text { S. palinacanthum Dunal } \\
\text { S. paniculatum Linnaues } \\
\end{array}$ \\
\hline
\end{tabular}



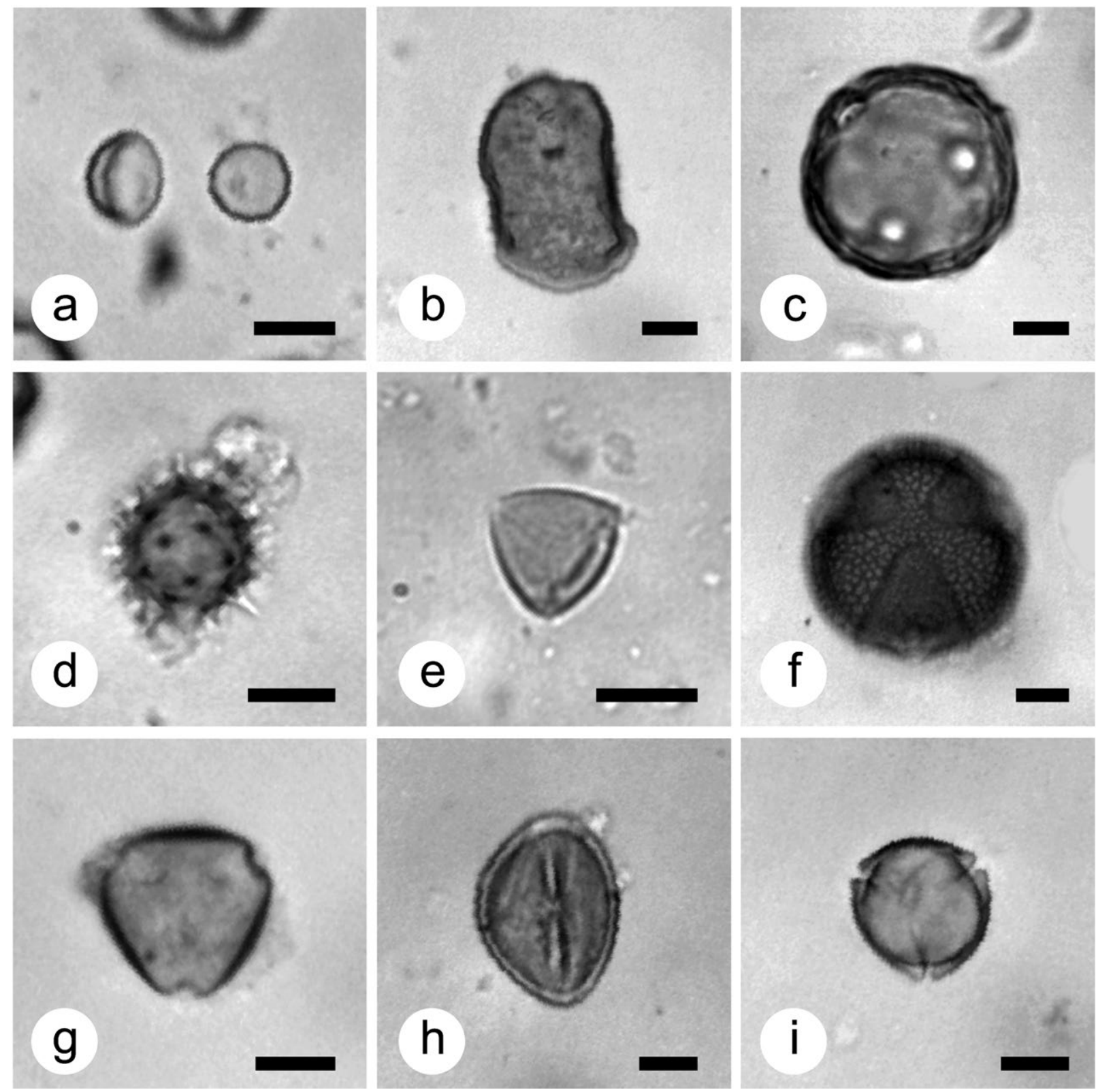

Fig. 3. Photomicrographs of some of the pollen types recorded in pollen stores of Tetragonisca angustula foraging in caatinga (seasonally dry tropical forest) vegetation in Northeastern Brazil. a - Brosimum, Moraceae; b - Geonoma, Arecaceae; c - Heteropterys, Malpighiaceae; d - Mikania, Asteraceae; e - Myrcia, Myrtaceae; $\mathrm{f}$ - Poincianella pyramidalis, Fabaceae; $\mathrm{g}$ - Prosopis juliflora, Fabaceae; $\mathrm{h}$ - Senna macranthera, Fabaceae; i - Solanum, Solanaceae. Bars $=10 \mu \mathrm{m}$.

(Jan-Mar and May-Dec 2011), Senna macranthera (Apr-Dec 2011) and Heteropterys (Sep-Dec 2011) (Table 2).

In the months when the collections were performed at both study sites, the number of pollen types identified in the samples from Itaberaba each month was slightly lower than at Ruy Barbosa (Fig. 2, Tables 1 and 2). Furthermore, in these months, the number of pollen types recorded simultaneously in the spectra for the two areas varied from three (in Jan and Apr 2011) to eight (in Dec 2011) (an average of $4 \pm 1.5$ s.d., $n=9$ ) (Fig. 2, Table 3). In total, eleven pollen types were recorded in the samples of pollen collected by Tetragonisca angustula in the same months at Itaberaba and Ruy Barbosa, and include the families Anacardiaceae, Arecaceae, Asteraceae, Faba- ceae, Malpighiaceae, Malvaceae, Moraceae, Myrtaceae and Solanaceae (Table 3, Fig. 3).

The ecological analysis indicates that the average trophic niche breadth of T. angustula at Itaberaba was $1.10 \pm$ 0.46 s.d. $(n=13)$. The month with the smallest niche breadth was Jan $2011\left(\mathrm{H}^{\prime}=0.42\right)$ and the largest was Dec $2011\left(H^{\prime}=1.79\right)$ (Fig. 4, Table 1). At Ruy Barbosa, the average $H^{\prime}$ index was $1.11 \pm 0.35$ s.d. $(n=10)$, with minimum and maximum values recorded in Sep 2011 (H' $=0.65)$ and Dec $2011\left(\mathrm{H}^{\prime}=1.76\right)$, respectively (Fig. 4, Table 2).

The average equitability at Itaberaba was $0.50 \pm 0.15$ s.d. $(n=13)$, with the minimum and maximum recorded in Jan $2011\left(\mathrm{~J}^{\prime}=0.24\right)$ and Jun $2011\left(\mathrm{~J}^{\prime}=0.69\right)$, respectively (Fig. 4, Tables 1 and 2). At Ruy Barbosa, the 

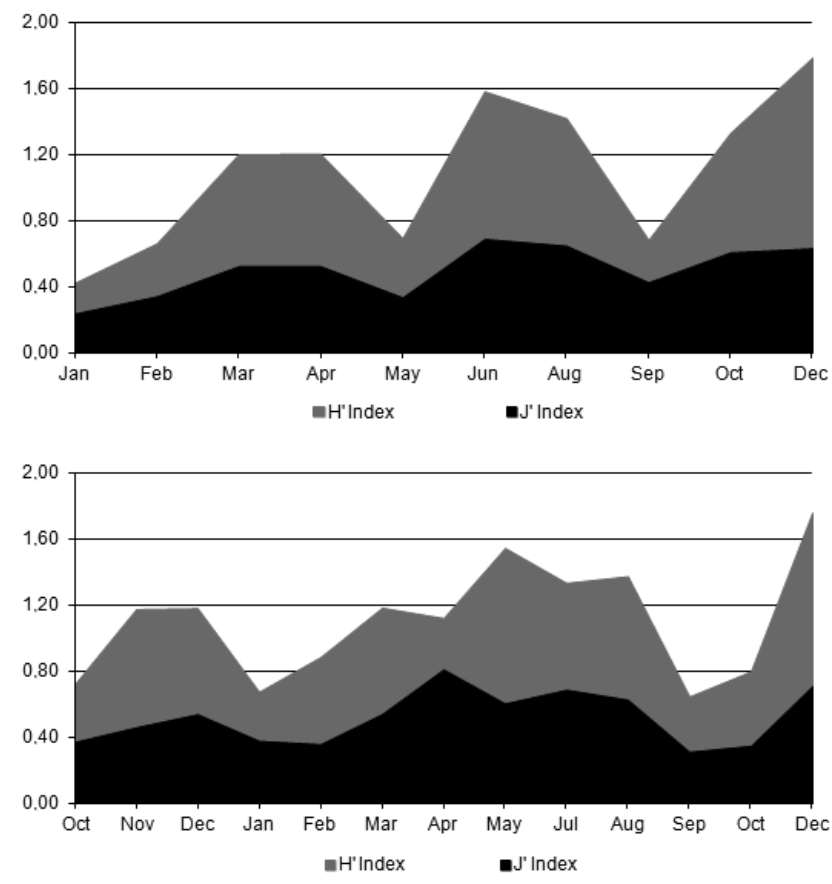

Fig. 4. Monthly variation in pollen niche breadth ( $\mathrm{H}^{\prime}$ index) and equitability ( $\mathrm{J}$ ' index) in samples of pollen collected from pollen stores of Tetragonisca angustula colonies in the municipalities of Itaberaba (upper graph) and Ruy Barbosa (lower graph), in the semiarid region of Bahia, Northeastern Brazil.

average J' value was $0.52 \pm 0.16$ s.d. $(n=10)$, with a minimum and maximum recorded in Sep $2011\left(\mathrm{~J}^{\prime}=0.31\right)$ and Apr $2011\left(\mathrm{~J}^{\prime}=0.81\right)$, respectively (Fig. 4, Tables 1 and 2).

The monthly H' and J' values for Itaberaba decreased or increased in parallel (Table 1). At Ruy Barbosa, however, this parallelism in behaviour was not consistent. In 2011, in Feb-Mar and Mar-Apr, opposite trends were recorded in the H' and J' values: the H' index decreased when the J' value increased and vice versa (Table 2).

\section{DISCUSSION AND CONCLUSIONS}

This study indicates that $T$. angustula collected pollen from a wide spectrum of flowers but especially from Prosopis juliflora (Fabaceae) and Solanum Linnaeus spp. (Solanaceae), which makes up a major part of the pollen spectrum throughout most of the period studied. The consistent use of certain floral sources by the bees and other pollinators may reflect the ability of these insects to "learn" or "memorize" their floral characteristics, such as colour, odour, size, and patterns, which function as indicators of rewards, such as nectar, pollen or resin (Gonzalez et al., 1995; Chittka et al., 1999; Glover, 2007; Nicolson, 2007). Although the search for particular flower sources can often be inferred from pollen spectra, this fact does not necessarily imply that these species provide a greater amount of the resource than other species. Chittka et al. (1999) suggest that in the search for a preferred species, bees could neglect flowers of other species of plants that offer as much or more of the resource than the preferred plants. In addition, pollen is not always a reliable indicator of a nectar source because there are no in depth studies of how the availability of resources varies even within the same genus or of the floral and reproductive biology of a large number of species of plants in areas such as the caatinga (Iwama \& Melhem, 1979; Machado \& Lopes, 2004; Santos et al., 2010; Roubik \& Moreno, 2013). Therefore, it is essential to carry out more field studies to ratify or rectify the inferences made based on pollen spectra (Roubik \& Moreno, 2013).

The pollen grains in bee products provide clues to their geographical origin because the key plant species that characterize the region where they were produced can be identified (Maurizio, 1975; Louveaux et al., 1978). Giulietti et al. (2002) lists 318 species endemic to areas of caatinga in Northeastern Brazil. Of the genera identified in this study, 13 were represented in the pollen spectra recorded for Itaberaba and Ruy Barbosa, however, only a few of these can be considered to be geographical indicators of this type of vegetation, such as Poincianella pyramidalis, Senna macranthera and Zornia echinocarpa (Giulietti et al., 2004).

Queiroz (2008) reports that Poincianella pyramidalis (Tulasne) L.P. Queiroz var. pyramidalis is characteristic of areas of sensu stricto caatinga, where small-sized trees are predominant but do not form a continuous canopy, the trees and bushes exhibit xerophytic characteristics and the herbaceous plant layer is only present during the rainy season. $P$. pyramidalis var. pyramidalis is typical of the state of Bahia and adjacent regions of caatinga in Pernambuco and Alagoas States, mainly occurring in arboreal caatinga. The majority of the insects visiting the flowers of $P$. pyramidalis seek nectar, although the volume of this resource per flower is limited, which may cause the visitor to forage from a larger number of flowers, thereby increasing the chance of effectively pollinating the species (Leite \& Machado, 2009).

There are three different varieties of Senna macranthera (de Candolle ex Colladon) H.S. Irwin \& Barneby occurring in areas of caatinga (Queiroz, 2008), of which only $S$. macranthera var. micans (Nees) H.S. Irwin \& Barneby is reported by Cardoso and Queiroz (2008) in the region of the Serra do Orobó [Orobó Mountains] in the municipalities of Itaberaba and Ruy Barbosa. Pollen from the genus Senna Miller is recorded in various palynological studies carried out in areas of caatinga (Novais et al., 2009; Oliveira et al., 2010; Silva et al., 2012) and $S$. macranthera is an important source of pollen used by the bees in this type of vegetation (Maia-Silva et al., 2012). It is likely that $T$. angustula can collect the pollen remaining in the flowers of this species after their anthers have been shaken by the vibrations generated by larger bees, such as those of the genera Xylocopa Latreille and Bombus Latreille (Machado \& Lopes, 2004; Maia-Silva et al., 2012).

Queiroz (2008) reports that Zornia echinocarpa (Moricand ex Meissner) Bentham occurs in restinga (coastal vegetation) and caatinga on sandy soil only in the state of Bahia. Cardoso \& Queiroz (2008) confirm the presence of this species in the Serra do Orobó. Pollen from Zornia echinocarpa is among the dominant types in the pollen 
loads of Apis mellifera Linnaeus foraging in the caatinga region of Canudos, Bahia (Novais et al., 2010). In our study, Zornia echinocarpa pollen was present at a low level in the spectra.

In contrast, pollen types indicating genera and species important for bees in the caatinga region are recorded, both in nectar [e.g., Prosopis juliflora (Fabaceae) and Waltheria Linnaeus (Malvaceae)] and pollen [e.g., Solanum (Solanaceae)] (Machado \& Lopes, 2004; Santos et al., 2006; Maia-Silva et al., 2012). The Prosopis juliflora pollen type occurred most frequently in the samples studied. This species is not native to caatinga, however, it occurs spontaneously in various regions where agricultural activities have ceased (Queiroz, 2008). Prosopis juliflora may be pre-adapted to surviving in caatinga because of its rapid growth and resistance to drought (Sajjad et al., 2012). In the study areas, this species flowered practically throughout the entire year, constituting a continuous source of resources for local bees.

Other sources of pollen for bees in the study areas were the genera Brosimum Swartz, which is common in pollen spectra although predominantly an anemophilous species (Martins \& Batalha, 2006), and Virola Aublet (Lena \& Oliveira, 2006). Cesário \& Gaglianone (2008) report that the simple flowers of Schinus Linnaeus are a source of pollen and nectar for various species of insect. Heteropterys Kunth, although considered to be a source of oil for Centridini bees in areas of caatinga (Aguiar et al., 2003), was also regularly visited during several months at Itaberaba and Ruy Barbosa and, therefore, is also a pollen source (Rocha-Filho et al., 2012).

Compared with that of other Meliponini, the trophic niche of Tetragonisca angustula is relatively small (H' < 1.5 ) in the two areas studied (Carvalho et al., 1999; Oliveira et al., 2009; Ferreira et al., 2010). However, values close to those recorded in our study were obtained for T. angustula at other Brazilian locations. Novais \& Absy (2013) investigated the pollen stored by T. angustula at Belterra $\left(\mathrm{H}^{\prime}=1.04\right)$ and Santarém $\left(\mathrm{H}^{\prime}=0.59\right)$ in the state of Pará, Carvalho et al. (1999) analyzed corbicular pollen stored by this species at Piracicaba, São Paulo $\left(\mathrm{H}^{\prime}=2.70\right)$ and Morgado et al. (2011) investigated corbicular pollen stored by $T$. angustula foraging in the Ilha Grande, Rio de Janeiro $\left(H^{\prime}=0.43\right)$. It is likely that the small size of $T$. angustula determines the small size of its pollen niche in different ecosystems.

In general, the trends in $\mathrm{H}^{\prime}$ and J' run parallel with one another. However, in some cases, this is not the case as was recorded from November to December 2010, at Ruy Barbosa. Although the value of H' was the same (1.18) in both months, that of J' increased (from 0.46 to 0.54 ), due to the decrease in the dominance of the pollen of Prosopis juliflora, which was the predominant pollen $(71.01 \%)$ in November 2010. While the most dominant pollen type in December 2010 was Solanum pollen type (57.12\%), but at a frequency lower than that recorded for Prosopis juliflora in the previous month. In contrast, in December 2010 , the frequency of $P$. juliflora pollen was $17.97 \%$. Thus, the co-dominance of the Solanum and Prosopis juliflora pollen types in December 2010 may explain the increase in uniformity recorded in the spectrum $(\mathrm{J}$ ').

Another example occurred from April to May 2011 when there was an increase in $\mathrm{H}^{\prime}$ and a decrease in J'. This decline was due to the dominance of Solanum pollen type (54.88\%). In April 2010, Prosopis juliflora dominated the spectrum (54.91\%), followed by Solanum $(24.91 \%)$ and Senna macranthera (14.15\%). In May 2010 , the Solanum pollen type was followed by that of Prosopis juliflora (12 .37\%) and Heteropterys (11.67\%). The lowest values of these last two types, compared to the frequencies of Solanum and Senna macranthera in April 2010 , indicated a lower uniformity in the use of pollen resources in May 2010.

The uniform use of pollen sources was slightly lower at Itaberaba than at Ruy Barbosa. Carvalho et al. (1999) recorded that compared with Apis mellifera and three species of Meliponini of the genera Nannotrigona Cockerell, Partamona Schwarz and Plebeia Schwarz, T. angustula foraged less uniformly at Piracicaba (São Paulo). The diversity of floral sources used by Tetragonisca angustula, together with the consistency exhibited by this species in the use of these resources, confirmed the generalist habit of this species. The small size of this insect may result in reduced energy expenditure (Imperatriz-Fonseca et al., 1984) per flower while foraging and probably per minute of flight, making various plants equally attractive for supplying food rewards. We may hypothesize that flowers offering a low quantity of resource (pollen or nectar) should be almost as attractive to small bees as those which offer high pollen/nectar rewards. This can be advantageous if they are competing with other foragers for the same resources.

Therefore, we conclude that $T$. angustula exploits a significant number of species of plants in the study areas, which confirms that this species has a polylectic foraging strategy. A number of species of plants can be used as indicators of caatinga vegetation, such as Poincianella pyramidalis and Senna macranthera. The pollen types Prosopis juliflora and Solanum were the most frequently recorded in the samples, demonstrating their prioritization as sources of pollen by Tetragonisca angustula at Itaberaba and Ruy Barbosa. The ecological analyses indicated a homogeneous use of floral resources by T. angustula in the areas of caatinga studied. High homogeneity implies low dominance of a single pollen type in the pollen spectrum. That the exotic Prosopis juliflora is such an important source of pollen for this native bee may have implications for the interactions between native and non-native species in this and other eco-regions that contain generalist species with broad niches.

ACKNOWLEDGEMENTS. The authors thank C. de Souza Dias for contacting the bee keepers who provided samples from their private apiary; the regional office of the Bahia Company of Agricultural Development (EBDA, Empresa Baiana de Desenvolvimento Agrícola S.A.) in Itaberaba for their logistic support; the board of directors of the Agricultural Family School Mãe Jovina for access to the apiary at the institution in Ruy Barbosa; the beekeepers Alex and Manoel for providing samples for the study; B.H. Andrade-Silva for his help in the field and labora- 
tory; L. Santos Damascena for generating the map used in this study; and the National Council of Scientific and Technological Development (CNPq, Conselho Nacional de Desenvolvimento Científico e Tecnológico) for partially financing this study and for the following grants: 575747/2008-0, 143084/2009-7, $303557 / 2010-9$ and 477127/2011-8.

\section{REFERENCES}

Aguiar C.M.L., Zanella F.C.V., Martins C.F. \& Carvalho C.A.L. 2003: Plantas visitadas por Centris spp. (Hymenoptera: Apidae) na caatinga para obtenção de recursos florais. - Neotrop. Entomol. 32: 247-259.

Albuquerque U.P., Araújo E.L., El-Deir A.C.A., Lima A.L.A., Souto A., Bezerra B.M., Ferraz E.M.N., Freire E.M.X., Sampaio E.V.S.B., Las-Casas F.M.G., Moura G.J.B., Pereira G.A., Melo J.G., Ramos M.A., Rodal M.J.N., Schiel N., Lyra-Neves R.M., Alves R.R.N., Azevedo-Júnior S.M., TElino JÚNIOR W.R. \& SEVERI W. 2012: Caatinga revisited: ecology and conservation of an important seasonal dry forest. - The Scientific World Journal 2012 (Article ID 205182) doi: 10.1100/2012/205182.

Allen-Wardell G., Bernhardt P., Bitner R., Burquez A., Buchmann S., Cane J., Cox P.A., Dalton V., Feinsinger P., Inouye D., Ingram M., Jones C.E., Kennedy K., Nabham G.P., Pavlik B., Tepedino V., Torchio P. \& Walker S. 1998: The potential consequences of pollinator declines on the conservation of biodiversity and stability of food crop yields. Conserv. Biol. 12: 8-17.

AndRAde-Lima D. 1981: The caatinga dominium. - Rev. Bras. Bot. 4: 149-163.

BARTH O.M. 2004: Melissopalynology in Brazil: a review of pollen analysis of honeys, propolis and pollen loads of bees. - Sci. Agric. 61: 342-350.

BiesmeiJer J.C., Roberts S.P.M., Reemer M., Ohlemüller R., Edward M., Peeters T., Schaffers A.P., Potts S.G., Kleukers R., Thomas C.D., Settele J. \& Kunin W.E. 2006: Parallel declines in pollinators and insect-pollinated plants in Britain and the Netherlands. - Science 313: 351-354.

Borges R.L.B., Lima L.C.L., Oliveira P.P., Silva F.H.M., Novais J.S., Dórea M.C. \& Santos F.A.R. 2006: O pólen no mel do semi-árido brasileiro. In Santos F.A.R. (ed.): Apium Plantae. IMSEAR, Recife, PE, pp. 103-118.

BuRKLE L.A. \& ALARCón R. 2011: The future of plant-pollinator diversity: understanding interaction networks across time, space, and global change. - Am. J. Bot. 98: 528-538.

Camargo J.M.F. \& Pedro S.R.M. 2012: Meliponini Lepeletier, 1836. In Moure J.S., Urban D. \& Melo G.A.R. (orgs): Catalogue of Bees (Hymenoptera, Apoidea) in the Neotropical Region - online version. Available at http:// www.moure.cria.org.br/catalogue. Accessed on 16 Apr. 2013.

CARDoso D.B.O.S. \& QueIroz L.P. 2008: Floristic composition of seasonally dry tropical forest fragments in Central Bahia, Northeastern Brazil. - J. Bot. Res. Inst. Texas 2: 551-573.

Carvalho C.A.L., Marchini L.C. \& Ros P.B. 1999: Fontes de pólen utilizadas por Apis mellifera L. e algumas espécies de Trigonini (Apidae) em Piracicaba (SP). — Bragantia 58: $49-56$.

Cesário L.F. \& Gaglianone M.C. 2008: Biologia floral e biologia reprodutiva de Schinus terebinthifolius Raddi (Anacardiaceae) em restinga do Norte Fluminense. - Acta Bot. Bras. 22: 828-833.

Chittka L., Thomson J.D. \& Waser N.M. 1999: Flower constancy, insect psychology, and plant evolution. Naturwissenschaften 86: 361-377.
EMBRAPA - Monitoramento por Satélite 2013: Banco de Dados Climáticos do Brasil. Available on http:// www.bdclima.cnpm.embrapa.br/resultados/index.php?UF=ba. Accessed on 17 Apr. 2013.

ErdtMan G. 1960: The acetolysis method - a revised description. - Sv. Bot. Tidskr. 54: 561-564.

Ferreira M.G., Manente-Balestieri F.C.D. \& Balestieri J.B.P. 2010: Pólen coletado por Scaptotrigona depilis (Moure) (Hymenoptera, Meliponini), na região de Dourados, Mato Grosso do Sul, Brasil. - Rev. Bras. Entomol. 54: 258-262.

Forzza R.C., Baumgratz J.F.A., Bicudo C.E.M., Canhos D.A.L., Carvalho JR A.A., Costa A., Costa D.P., Hopkins M., Leitman P.M., Lohmann L.G., Lughadha E.N., Maia L.C., Martinelli G., Menezes M., Morim M.P., Coelho M.A.N., Peixoto A.L., Pirani J.R., Prado J., Queiroz L.P., Souza S., Souza V.C., Stehmann J.R., Sylvestre L.S., WALTER B.M.T. \& ZAPPI D. 2010: Síntese da diversidade brasileira. In Forzza R.C. et al. (orgs): Catálogo de Plantas e Fungos do Brasil. Vol. 1. Andrea Jakobsson Estúdio, Instituto de Pesquisas Jardim Botânico do Rio de Janeiro, Rio de Janeiro, RJ, pp. 21-42.

Freitas B.M., Imperatriz-Fonseca V.L., Medina L.M., Kleinert A.M.P., Galetto L., Nates-Parra G. \& Quezada-Euán J.J.G. 2009: Diversity, threats and conservation of native bees in the Neotropics. - Apidologie 40: 332-346.

Giannini T.C., Acosta A.L., Garófalo C.A., Saraiva A.M., Alves-dos-Santos I. \& Imperatriz-Fonseca V.L. 2012: Pollination services at risk: bee habitats will decrease owing to climate change in Brazil. - Ecol. Model. 244: 127-131.

Giulietti A.M., Harley R.M., Queiroz L.P., Barbosa M.R.V., Du Bocage Neta A.L. \& Figueiredo M.A. 2002: Espécies endêmicas da caatinga. In Sampaio E.V.S.B., Giulietti A.M., Virgínio J. \& Gamarra-Rojas C.F.L. (eds): Vegetação e Flora da Caatinga. APNE/CNIEB, Recife, PE, pp. 103-108.

Giulietti A.M., Du Bocage Neta A.L., Castro A.A.J.F., Gamarra-Rojas C.F.L., Sampaio E.V.S.B., Virgínio J.F., Queiroz L.P., Figueiredo M.A., Rodal M.J.N., Barbosa M.R.V. \& HARLeY R.M. 2004: Diagnóstico da vegetação nativa do bioma caatinga. In Silva J.M.C., Tabarelli M., Fonseca M.T. \& Lins L.V. (orgs): Biodiversidade da Caatinga: Áreas e Ações Prioritárias para a Conservação. MMA, Brasília, DF, pp. 47-90.

Giulietti A.M., Rapini A., Andrade M.J.G., Queiroz L.P. \& Silva J.M.C. (orgs) 2009: Plantas Raras do Brasil. Conservação Internacional, Universidade Estadual de Feira de Santana, Belo Horizonte, MG, 496 pp.

GLOVER B. 2007: Do pollinators discriminate between different floral forms? In Glover B.: Understanding Flowers and Flowering: An Integrated Approach. Oxford University Press, Oxford, pp. 181-191.

Gonzalez A., Rowe C.L., Weeks P.J., Whittle D., Gilbert F.S. \& BARNARD C.J. 1995: Flower choice by honey bees (Apis mellifera L.): sex-phase of flowers and preferences among nectar and pollen foragers. - Oecologia 101: 258-264.

HAMmer Ø., Harper D.A.T. \& RYAN P.D. 2001: PAST: Palaeontological Statistics software package for education and data analysis. - Palaeontologia Electronica 4(1). Available at http://palaeo-electronica.org/2001_1/past/issue1_01.htm. Accessed on 17 Apr. 2013.

Imperatriz-Fonseca V.L., Kleinert-Giovannini A., CortopassiLaurino M. \& Ramalho M. 1984: Hábitos de coleta de Tetragonisca angustula angustula Latreille (Apidae, Meliponinae). - Bolm. Zool. Univ. S. Paulo 8: 115-131.

International Pollinators Initiative 1999: The São Paulo Declaration on Pollinators. Report on the Recommendations of the Workshop on the Conservation and Sustainable Use of 
Pollinators in Agriculture with Emphasis on Bees. Brazilian Ministry of the Environment (MMA), Brasilia, DF, $66 \mathrm{pp}$ Available at http://www.cbd.int/doc/case-studies/agr/cs-agrpollinator-rpt.pdf. Accessed on 16 Apr. 2013.

Iwama S. \& MelHem T.S. 1979: The pollen spectrum of the honey of Tetragonisca angustula angustula Latreille (Apidae, Meliponinae). - Apidologie 10: 275-295.

Jones G.D. \& BRyant JR V.M. 1996: Melissopalynology. In Jansonius J. \& McGregor D.C. (eds): Palynology: Principles and Applications. Vol. 3. AASP Foundation, Dallas, pp. 933-938.

Joosten H. \& DE KLerK P. 2002: What's in a name? Some thoughts on pollen classification, identification, and nomenclature in Quaternary palynology. - Rev. Palaeobot. Palynol. 122: 29-45.

Leite A.V. \& Machado I.C. 2009: Biologia reprodutiva da "catingueira" (Caesalpinia pyramidalis Tul., LeguminosaeCaesalpinioideae), uma espécie endêmica da caatinga. Revista Brasil. Bot. 32: 79-88.

Lena E. \& Oliveira P.E. 2006: Biologia reprodutiva e fenologia de Virola sebifera Aubl. (Myristicaceae) em mata mesofítica de Uberlândia, MG, Brasil. — Revista Brasil. Bot. 29: 443-451.

Louveaux J., Maurizio A. \& Vorwohl G. 1978: Methods of melissopalynology. - Bee World 59(4): 139-157.

Machado I.C. \& Lopes A.V. 2004: Floral traits and pollination systems in the caatinga, a Brazilian tropical dry forest. Ann. Bot. 94: 365-376.

Maia-Silva C., Silva C.I., Hrncir M., Queiroz R.T. \& IMPERATRIz-FonseCA V.L. 2012: Guia de Plantas Visitadas por Abelhas na Caatinga. Fundação Brasil Cidadão, Fortaleza, CE, $191 \mathrm{pp}$.

Martins F.Q. \& Batalha M.A. 2006: Pollination systems and floral traits in cerrado woody species of the Upper Taquari region (Central Brazil). — Braz. J. Biol. (A) 66: 543-552.

Maurizio A. 1975: Microscopy of honey. In Maurizio A. (ed.): Honey: A Comprehensive Survey. William Heinemann, London, pp. 240-257.

Michener C.D. 2007: The Bees of the World. 2nd. ed. The Johns Hopkins University Press, Baltimore, MD, $953 \mathrm{pp}$.

Morgado L.N., Andrade R.C., Lorenzon M.C.A. \& GonÇalves-Esteves V. 2011: Padrão polínico utilizado por Tetragonisca angustula Latreille (Apidae: Meliponina). Acta Bot. Bras. 25: 932-934.

Nicolson S.W. 2007: Nectar consumers. In Nicolson S.W., Nepi M. \& Pacini E. (eds): Nectaries and Nectar. Springer, Dordrecht, pp. 289-342.

NovaIS J.S. \& ABSY M.L. 2013: Palynological examination of the pollen pots of native stingless bees from the Lower Amazon region in Pará, Brazil. - Palynology doi: 10.1080/01916122.2013.787127.

Novais J.S., Lima L.C.L. \& SAntos F.A.R. 2006: Espectro polínico de méis de Tetragonisca angustula Latreille, 1811 coletados na caatinga de Canudos, Bahia, Brasil. — Magistra 18: $257-264$.

Novais J.S., Lima L.C.L. \& Santos F.A.R. 2009: Botanical affinity of pollen harvested by Apis mellifera $\mathrm{L}$. in a semi-arid area from Bahia, Brazil. — Grana 48: 224-234.

Novais J.S., Lima L.C.L. \& Santos F.A.R. 2010: Bee pollen loads and their use in indicating flowering in the caatinga region of Brazil. - J. Arid Environ. 74: 1355-1358.

Novais J.S., Absy M.L. \& Santos F.A.R. in press. Pollen grains in honeys produced by Tetragonisca angustula (Latreille, 1811) (Hymenoptera: Apidae) in tropical semi-arid areas of north-eastern Brazil. Arthropod-Plant Interactions doi: 10.1007/s11829-013-9276-x.
Oliveira F.P.M., Absy M.L. \& Miranda I.S. 2009: Recurso polínico coletado por abelhas sem ferrão (Apidae, Meliponinae) em um fragmento de floresta na região de Manaus Amazonas. - Acta Amaz. 39: 505-518.

Oliveira P.P., van den Berg C. \& Santos F.A.R. 2010: Pollen analysis of honeys from caatinga vegetation of the state of Bahia, Brazil. - Grana 49: 66-75.

Pielou E.C. 1977: Mathematical Ecology. 2nd ed. WilleyInterscience Publication, John Willey \& Sons, New York, NY, 385 pp.

Prado D. 2003: As caatingas da América do Sul. In Leal I.R., Tabarelli M. \& Silva J.M.C. (eds): Ecologia e Conservação da Caatinga. Universitária da UFPE, Recife, PE, pp. 3-73.

Prado D.E. \& GibBs P.E. 1993: Patterns of species distributions in the dry seasonal forest of South America. - Ann. Missouri Bot. Gard. 80: 902-927.

QueIroz L.P. 2006: The Brazilian caatinga: phytogeographical patterns inferred from distribution data of the Leguminosae. In Pennington T., Lewis G.P. \& Ratter J.A. (eds): Neotropical Savannas and Seasonally Dry Forests: Plant Diversity, Biogeography and Conservation. CRC Press, Boca Raton, FL, pp. 121-157.

QueIroz L.P. 2008: Leguminosas da Caatinga. UEFS, Feira de Santana, BA, $467 \mathrm{pp}$

Ramalho M., Imperatriz-Fonseca V.L., Kleinert-Giovannini A. \& Cortopassi-Laurino M. 1985: Exploitation of floral resources by Plebeia remota Holmberg (Apidae, Meliponinae). - Apidologie 16: 307-330.

RizzinI C.T. 1963: Nota prévia sobre a divisão fitogeográfica do Brasil. - Rev. Bras. Geogr. 25: 3-64.

Rocha-Filho L.C., Krug C., Silva C.I. \& Garófalo C.A. 2012: Floral resource used by Euglossini bees (Hymenoptera: Apidae) in coastal ecosystems of the Atlantic forest. - Psyche 2013 (Article ID 934951) doi:10.1155/2012/934951.

RoubiK D.W. \& Moreno P.J.E. 1991: Pollen and Spores of Barro Colorado Island. MBG Press, St. Louis, MO, 286 pp.

RoubIK D.W. \& Moreno P.J.E. 2013: How to be a bee-botanist using pollen spectra. In Vit P., Pedro S.R.M. \& Roubik D. (eds): Pot-Honey: A Legacy of Stingless Bees. Springer, New York, NY, pp. 295-314.

SajJad A., Saeed S. \& Bashir M.A. 2012: Spatial variation in pollinator communities and reproductive performance of Prosopis juliflora (Fabaceae). - J. Poll. Ecol. 8(9): 59-66.

Santos F.A.R., Oliveira J.M., Oliveira P.P., Leite K.R.B. \& CARNEIRo C.E. 2006: Plantas do semi-árido importantes para as abelhas. In Santos F.A.R. (ed.): Apium Plantae. IMSEAR, Recife, PE, pp. 61-86.

Santos A.P.M., Romero R. \& Oliveira P.E.A.M. 2010: Biologia reprodutiva de Miconia angelana (Melastomataceae), endêmica da Serra da Canastra, Minas Gerais. - Revista Brasil. Bot. 33: 333-341.

SHannon C.E. \& Weaver W. 1949: The Mathematical Theory of Communication. Univ. of Illinois Press, Urbano, IL, 117 pp.

Silva F.H.M. 2007: Contribuição à Palinologia das Caatingas. Bahia State Univ. at Feira de Santana, Feira de Santana, BA, $182 \mathrm{pp}$.

Silva A.P.C., Lima Á.S. \& Santos F.A.R. 2012: Botanical biodiversity in honey samples from the semiarid region of Sergipe state, Brazil. - Magistra 24: 158-171.

Zanella F.C.V. \& Martins C.F. 2003: Abelhas da caatinga: biogeografia, ecologia e conservação. In Leal I.R., Tabarelli M. \& Silva J.M.C. (eds): Ecologia e Conservação da Caatinga. Ed. Universitária da UFPE, Recife, PE, pp. 75-134.

Received May 9, 2013; revised and accepted September 6, 2013 